\title{
BMJ Open Life under COVID-19 for LGBT+ people in the UK: systematic review of UK research on the impact of COVID-19 on sexual and gender minority populations
}

\author{
Victoria J McGowan, ${ }^{1}$ Hayley J Lowther (D) , ${ }^{2}$ Catherine Meads (D) ${ }^{3}$
}

To cite: McGowan VJ, Lowther HJ, Meads C. Life under COVID-19 for LGBT+ people in the UK: systematic review of UK research on the impact of COVID-19 on sexual and gender minority populations. BMJ Open 2021;11:e050092. doi:10.1136/ bmjopen-2021-050092

- Prepublication history and supplemental material for this paper is available online. To view these files, please visit the journal online (http://dx.doi org/10.1136/bmjopen-2021 050092).

Received 10 February 2021 Accepted 12 July 2021

A) Check for updates

(c) Author(s) (or their employer(s)) 2021. Re-use permitted under CC BY-NC. No commercial re-use. See rights and permissions. Published by BMJ.

${ }^{1}$ Population Health Sciences Institute, Newcastle University, Newcastle upon Tyne, UK

${ }^{2}$ Lancashire Applied Health Research Collaboration Hub (LARCH), University of Central Lancashire, Preston, UK

${ }^{3}$ Faculty of Health, Education,

Medicine and Social Care, Anglia Ruskin University-Cambridge Campus, Cambridge, UK

Correspondence to

Dr Catherine Meads; catherine.meads@aru.ac.uk

\section{ABSTRACT}

Objective To systematically review all published and unpublished evidence on the impact of the COVID-19 pandemic on the health and well-being of UK sexual and gender minority (LGBT+; lesbian, gay, bisexual, transgender, non-binary, intersex and queer) people.

Methods Any relevant studies with or without comparator were included, with outcomes of: COVID-19 incidence, hospitalisation rates, illness severity, death rates, other health and well-being. Six databases (platforms) were searched-CINAHL Plus (Ovid), Cochrane Central (Cochrane Library), Medline (Ovid), Embase (Ovid), Science Citation Index (Web of Science) and Scopus between 2019 and 2020 in December 2020, using synonyms for sexual and gender minorities and COVID-19 search terms. Data extraction and quality assessment (using the relevant Joanna Briggs checklist) were in duplicate with differences resolved through discussion. Results were tabulated and synthesis was through narrative description.

Results No published research was found on any outcomes. Eleven grey literature reports found to be of low quality were included, mostly conducted by small LGBT+ charities. Only four had heterosexual/cisgender comparators. Mental health and well-being, health behaviours, safety, social connectedness and access to routine healthcare all showed poorer or worse outcomes than comparators.

Conclusions Lack of research gives significant concern, given pre-existing health inequities. Social and structural factors may have contributed to poorer outcomes (mental health, well-being and access to healthcare). Paucity of evidence is driven by lack of routinely collected sexual orientation and gender identity data, possibly resulting from institutional homophobia/transphobia which needs to be addressed. Men are more at risk of serious illness from COVID-19 than women, so using data from trans women and men might have started to answer questions around whether higher rates were due to sex hormone or chromosomal effects. Routine data collection on sexual orientation and gender identity is required to examine the extent to which COVID-19 is widening pre-existing health inequalities. PROSPERO registration number CRD42020224304.

\section{BACKGROUND}

It has become increasingly clear that COVID-19 infection has had a disproportionately negative impact on many who already

\section{Strengths and limitations of this study}

- This is the first systematic review collating all available relevant research (published and unpublished). Until now, no research had been published in peerreviewed academic journals on the impact of the COVID-19 pandemic on the health and well-being of sexual and gender minority people in the UK, so the impact of COVID-19 on the LGBT+ (lesbian, gay, bisexual, transgender, non-binary, intersex and queer) community in the UK was largely unknown.

- Major strengths are the extensive searches conducted, consistent and verifiable systematic review methods, and the inclusion of grey literature reports.

- Lack of research is a severe limitation in that no evidence was found on COVID-19 incidence, hospitalisation rates, illness severity or death rates.

- The consistency of findings around mental health and well-being, health behaviours, safety, social connectedness and access to routine healthcare is a strength, in that they all tended to show poor outcomes, or worse outcomes from the LGBT+ populations compared with before the pandemic or compared with heterosexual/cisgender populations.

- Lastly, a strength is the demonstration that routine data collection on sexual orientation and gender identity is required to examine the extent to which COVID-19 is widening pre-existing health inequities.

face disadvantage and discrimination, particularly people who are deprived, from black and minority ethnic backgrounds, and older people. ${ }^{1}$ Moreover, COVID-19 is being experienced as a syndemic among these populations, in that it interacts with, and exacerbates, existing health inequalities. ${ }^{2}$ However, little has been available so far on the impact of the virus itself or on the results of the epidemic and social control of the population (lockdown and other restrictions) on people from the minority sexual orientation or gender identity (SOGI) communities despite preexisting health inequities. ${ }^{3}$ 
In September 2020, the European Commission presented their first-ever European Union (EU) Strategy for lesbian, gay, bisexual, transgender, non-binary, intersex and queer (LGBT+) equality. ${ }^{4}$ While progress in the EU and elsewhere has been made towards LGBT+ equality over the past years, discrimination against LGBT+ people persists, and the COVID-19 crisis has only exacerbated the situation, with a higher rate of violence and discrimination towards LGBT+ people reported. ${ }^{5}$ In the UK, this societal discrimination has been acknowledged following a large survey by the UK government. ${ }^{6}$ The ensuing UK government Action Plan stated that they were 'committed to tackling the burning injustices that LGBT people face'?

However, there have been few academic publications so far on the impact of the COVID-19 virus on the health and well-being of people from the LGBT+ communities. What has been published internationally suggests several potential health and well-being impacts. It has been shown that people from sexual and gender minorities experience poorer mental health, ${ }^{89}$ but this has been exacerbated by the COVID-19 virus and associated social control measures. ${ }^{10-13}$

There is evidence to suggest that COVID-19 disproportionately affects people with endocrine conditions, putting them at an increased risk of severe disease. ${ }^{14}$ Female reproductive steroids may protect against more severe disease ${ }^{15}$ and lesbians have lower reproductive rates than heterosexual women. ${ }^{16}$ Sexual minority women possibly have higher levels of testosterone than heterosexual women, ${ }^{17}$ and many transgender men and women are taking exogenous hormones. The oestrogens that transgender women take may reduce the severity of COVID-19 infection. ${ }^{18}$ Some gay men have reported casual sex during the pandemic, which may increase the risk of COVID-19. ${ }^{19}{ }^{20}$ Men who have sex with men, and transgender women, have higher rates of HIV, which may exacerbate the effects of the COVID-19 virus. ${ }^{21}$

In addition, it has been demonstrated that the greater the level of minority stress on a person from the sexual minority community, the greater the negative impact on their mental health. ${ }^{22}$ Minority stress may also adversely affect their physical health. ${ }^{23}$ This is probably also true for trans people but there is less evidence on this. ${ }^{24}$

Given these issues, routine data collection around SOGI would seem warranted. This systematic review reports all research on the impact of the COVID-19 pandemic on UK LGBT+ people.

\section{METHODS}

\section{Inclusion criteria}

Eligibility was: (1) Population: sexual minority people (self-described by orientation identity, sexual behaviour or marriage/cohabitation status), and transgender and non-binary people, living in the UK in any setting; (2) Exposure: COVID-19 pandemic; (3) Comparator 1: heterosexual people or those self-describing as only having sex with the opposite sex or married or cohabiting with someone from the opposite sex; and cisgender people; Comparator 2: life before the pandemic: Comparator 3: no comparator; (4) Outcomes: any relevant health and well-being outcomes; (5) Study design: any primary qualitative or quantitative studies of any design. Studies could be peer-reviewed, published or grey literature. Studies were excluded if: the sexual orientation and/or gender identity were not clear; there was no total number investigated in the report; there were fewer than $50 \%$ UK participants; there were no outcomes of interest; or if they were opinions, editorials or case reports.

\section{Search strategy, study selection and data extraction}

Searches were conducted by one reviewer $(\mathrm{CM})$ in November 2020 and checked by another (HJL). Search terms and appropriate synonyms (Medical Subject Headings terms and text words) were developed based on population and exposures. Six databases (platforms) were searched-CINAHL Plus (Ovid), Cochrane Central (Cochrane Library), Medline (Ovid), Embase (Ovid), Science Citation Index (Web of Science) and Scopus (Scopus platform). The same search terms were used for each database but adapted where necessary. All titles found were assessed for inclusion and abstracts read if available. A full table of search terms can be found in online supplemental table 1. Google searches used the terms COVID-19 and SOGI synonyms, and the first 100 hits were examined. Websites of UK LGBT+ charities were examined, as were reference lists of UK researchers in LGBT+ health and well-being research. The Office for National Statistics (ONS), and several health inequalities experts were contacted. Submissions to the UK Women and Equalities Select Committee Enquiry into COVID-19 and the impact on people with protected characteristics $^{25}$ were checked for primary research. If any titles and abstracts had relevant information or there was uncertainty, the full study was checked by two reviewers, with any disagreements resolved by discussion.

Standard forms were devised prior to data extraction and quality scoring, based on the aims of the systematic review. Data items included type of sample, number of participants in LGBT+ and comparator groups (if available), type of outcomes reported, any external funding, type of presentation, numerical results for each group under the general headings of incidence, hospitalisations, deaths, mental health, physical health, health behaviours, personal safety, social support, impact of the pandemic on being out and routine healthcare access. Information was extracted by one reviewer (CM) and checked by another (VJM). Staff from one study ${ }^{26}$ were contacted about data discrepancies and they supplied corrected data.

\section{Quality assessments}

Studies were quality assessed (CM and VJM) using the Joanna Briggs Institute (JBI) checklist for cross-sectional surveys. ${ }^{27}$ It was intended from the protocol to use Critical Appraisal Skills Programme (CASP) checklists, ${ }^{28}$ 
but all included studies were surveys and CASP has no survey checklist. The three external validity questions from $\mathrm{CASP}^{24}$ were used in addition to the JBI checklist. ${ }^{27}$ No funnel plot assessment of publication bias could be conducted due to lack of comparative numerical results.

\section{Data analysis}

Results for studies with the three types of comparators were tabulated separately. Where multiple SOGI subgroups were reported in the studies, these are presented separately. Numerical results (if given) were reported as percentages or means and SDs. Synthesis was by narrative description of results. Meta-analysis was not possible due to heterogeneity of study questions and lack of comparator populations.

\section{Patient and public involvement}

All authors of this paper are from, or allies with, the LGBT+ community. The first author discussed the idea of the systematic review with a number of LGBT+ activists and community workers, and there was unanimous consent that it was a good idea and would be very useful. A draft of the paper was peer reviewed by members of an LGBT+ charity based in the north east of England.

\section{RESULTS}

From 218 citations, 2 abstracts were selected for full-text examination, and no fully published papers were included. From internet searches and contacts with experts, 11 grey literature studies were found and included in the narrative synthesis (see online supplemental figure 1 for Preferred Reporting Items for Systematic Reviews and Meta-Analyses flow diagram and online supplemental table 2 for excluded studies with reasons for exclusion).

\section{Study characteristics}

The 11 studies were conducted in 2020 269-39 (see table 1).

All were grey literature reports, web pages with associated links to data or an unpublished manuscript intended for publication in a peer-reviewed journal. Nine were by charities and two were by pairs of academics, one with a small grant from the British Academy ${ }^{33}$ and the other was unfunded. $^{34}$

All studies were cross-sectional surveys conducted online, and all had quantitative data, nine also had qualitative components. All studies were UK based but there was limited geographical information provided, and no obvious participation from Wales, Scotland or Northern Ireland. Participants were recruited by a variety of methods, (advertising, word of mouth, social media), and all were internet surveys, one also included telephone contacts. ${ }^{39}$ Ages of participants varied, from all aged under 25 years $^{29}$ to the majority aged over 55 years. ${ }^{38}$ SOGI status for all studies was by self-report. Two studies reported results of heterosexual respondents ${ }^{263132}$ and two for cisgender respondents. ${ }^{26}{ }^{29}$ In all comparative studies, either the LGBT+ group or comparator group had fewer than 40 participants. One study framed survey questions in terms of changes since lockdown started ${ }^{36}$ and one study gave numerical results for before and during lockdown. ${ }^{26}$ The remaining studies gave results for LGBT+ people during the pandemic only.

All except one $e^{34}$ of the studies were found to be of relatively low quality when assessed from an academic background, as these studies were written for a lay audience. Checklist results are presented in online supplemental table 3. Very few methods were given for all but one ${ }^{34}$ of the reports-this manuscript gave in-depth methods for analysis of the collected data, including regression models. The two studies by academic groups 334 did have ethical approval, but it is not clear whether the other nine projects sought this. It was unclear if there were checks to ensure that the same person had not completed surveys more than once. External validity seemed reasonably good, with all studies finding similarly consistent outcomes.

\section{Findings}

Numerical results for studies with concurrent comparators are in table 2 and for historical comparators in table 3. Non-comparative study results are in tables 4 and 5 and online supplemental table $4 .{ }^{34}$

One small study ${ }^{39}$ reported the proportion of respondents who had had COVID-19 up to July 2020-5 of 103 respondents. There was no other information on rates of infection or hospitalisations.

Three studies with concurrent controls ${ }^{29} 29132$ reported mental health outcomes (see table 2), with also domestic violence, homelessness and self-harm in one. ${ }^{26}$ For two studies with heterosexual comparators, one ${ }^{31} 32$ found more in the LGBT+ group experienced poor mental health compared with the population as a whole. The other ${ }^{26}$ showed mixed results, with some poor outcomes experienced more often by LGB groups and some by heterosexual comparators. For example, more LGB respondents were at risk of homelessness, whereas more heterosexual respondents were self-harming. For two studies with cisgender comparison groups, ${ }^{26}{ }^{29}$ one found that all mental health outcomes (anxiety, depression, loneliness, self-harm) were worse for the trans respondents. ${ }^{26}$ Regarding health behaviours, exercise was less in the trans group but fewer had problems with alcohol consumption. ${ }^{26}$ More were at risk of homelessness. ${ }^{26}$ Particularly worrying were the findings ${ }^{29}$ which showed that more than double the percentages of trans young people with a variety of mental health difficulties compared with cisgender respondents. These included having mental health as a significant obstacle, feeling more lonely or isolated, and needing more support from a variety of service providers.

Both studies with historical comparators ${ }^{26}{ }^{35}$ reported worsening of all mental health and well-being outcomes during the COVID-19 pandemic (see table 3) for LGBT participants. There was worsening of anxiety, depression and self-harming in all groups in one study, ${ }^{26}$ and 


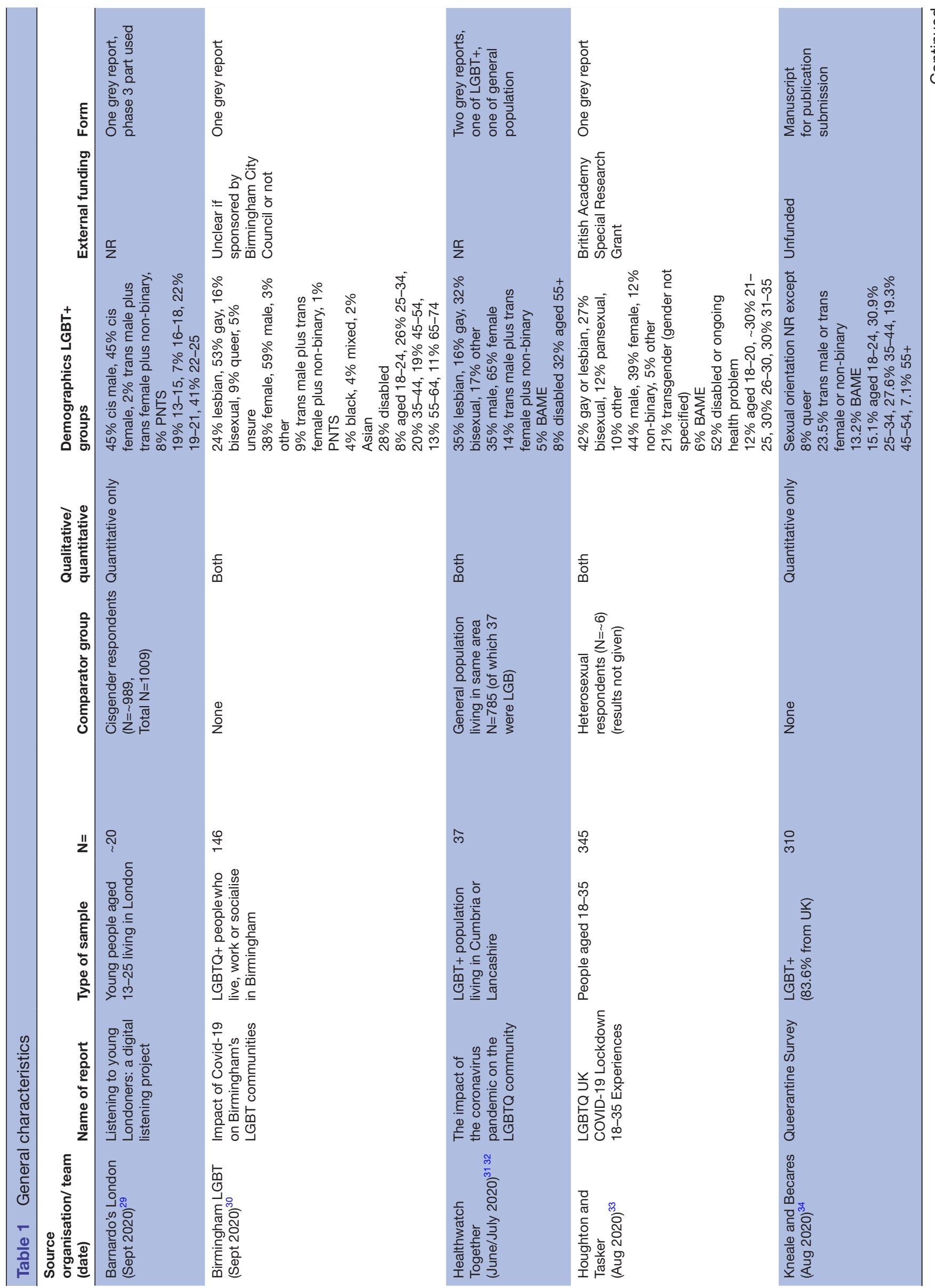




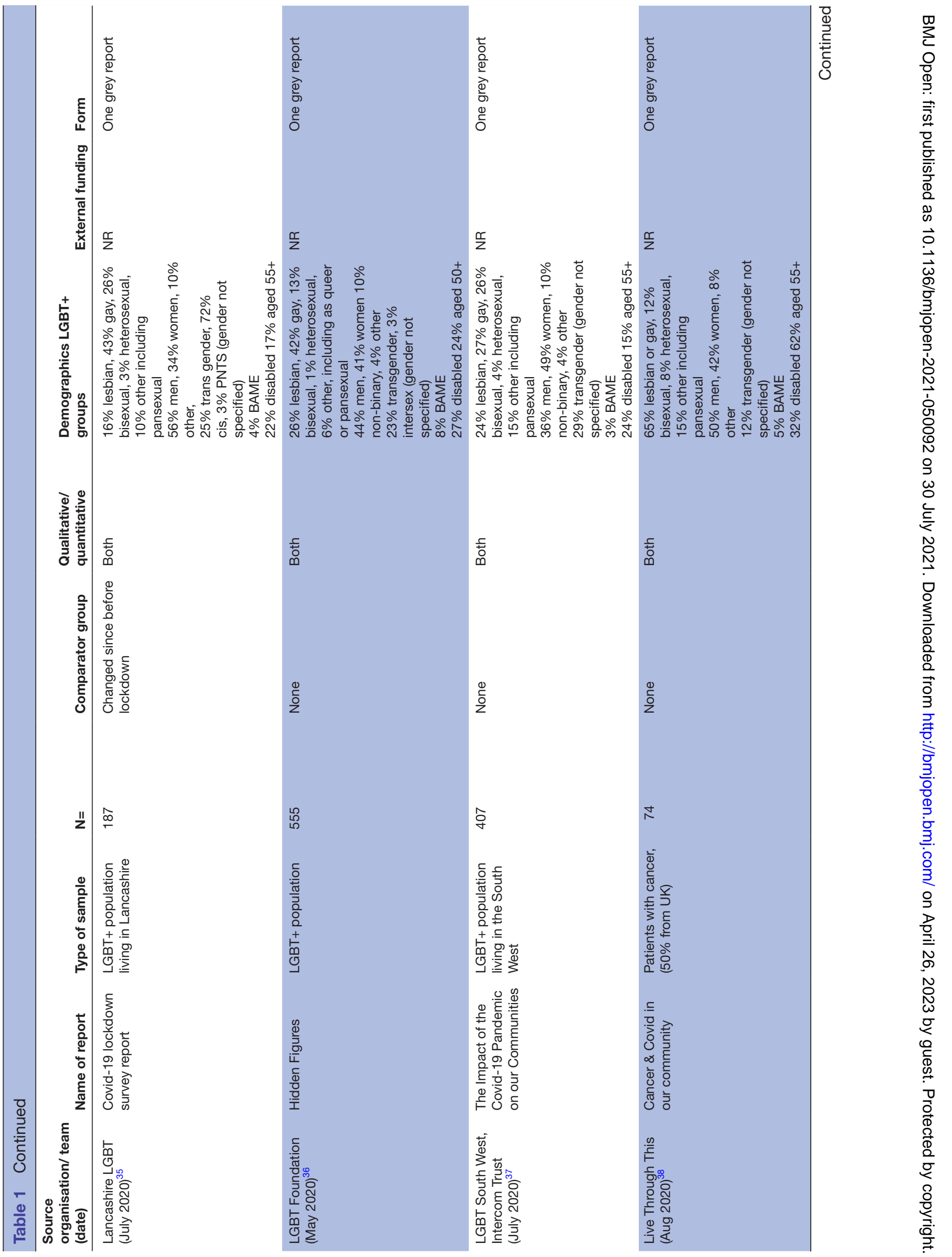




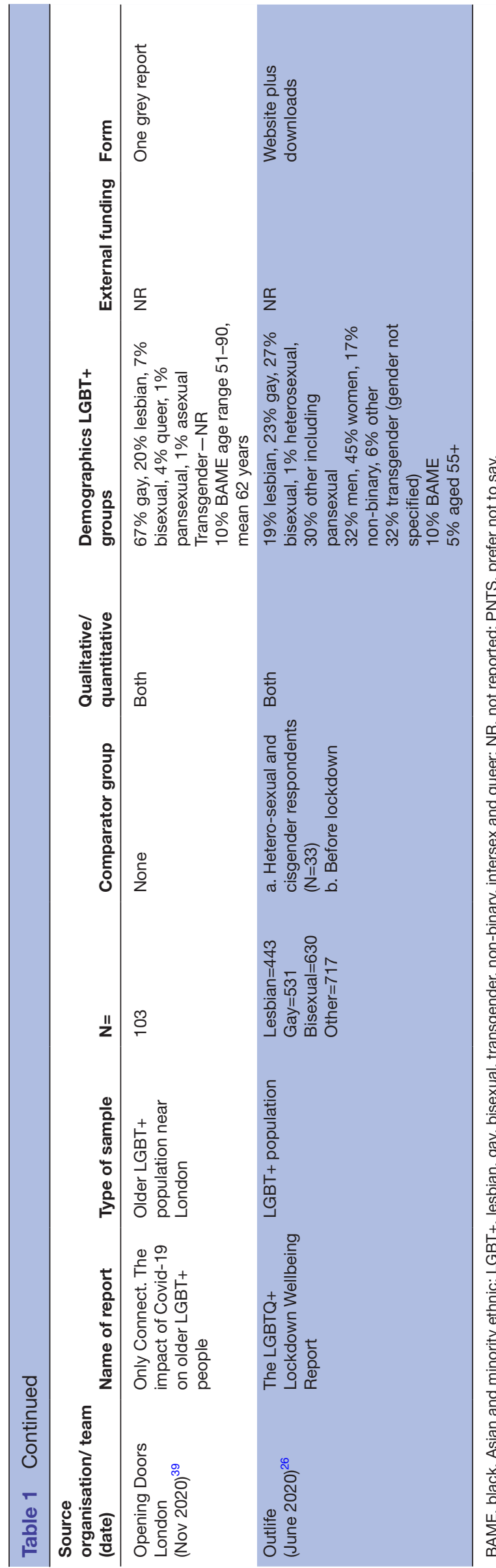

also considerable increases in the proportions reporting loneliness. The other study ${ }^{35}$ reported reductions in confidence, cheerfulness, feeling relaxed and good about themselves, feeling less close to others, thinking less clearly, dealing with problems less well for the whole group and reduction of well-being in trans people.

The eight non-comparative studies ${ }^{33-39}$ focused on general mental health, physical health, health behaviours (including alcohol consumption and use of other substances), personal safety, connectedness, being out and access to routine healthcare (see table 4 for health results and table 5 for well-being results). All studies showed that a sizeable proportion of respondents were worried about these issues. A high proportion felt that their mental health had been affected since the start of the pandemic, particularly regarding feelings of anxiety, depression, suicidal thoughts and self-harming behaviour. One study found high levels of perceived stress, with the average score increasing for those who had experienced an instance of homophobic or transphobic harassment, compared with respondents who had not. ${ }^{34}$ Similarly, the odds of exhibiting significant depressive symptomology increased threefold among those who had experienced harassment based on their gender or sexuality compared with those who had not. ${ }^{34}$ Many felt lonely and isolated from their partner, family and the LGBT community that they normally accessed. Many had little or no support from the community around them. In one study, a relatively high proportion reported knowing someone who had died from COVID-19. ${ }^{30}$ Access to healthcare was a major concern of many, particularly for trans people taking regular medication. Personal safety was another major concern, with a relatively high proportion not feeling safe where they were currently living, and three studies found relatively high proportions of people experiencing hate crime and domestic violence. ${ }^{3034} 35$ Also, a relatively high proportion felt that they could not be themselves during lockdown because they could not express their sexual orientation or gender identity. ${ }^{30} 3335$

\section{DISCUSSION}

\section{Statement of principal findings}

There has been alarmingly little research into the impact of the COVID-19 pandemic on the UK LGBT+ population, despite known pre-existing health inequities ${ }^{40}$ which is consistent with systematic review evidence regarding LGBT+ health inequalities in cancer, mental health and palliative care. ${ }^{41}$ What little there is focuses on mental health and well-being impacts, health behaviours, safety, social connectedness and access to routine healthcare. The general trend was for poor outcomes, or for worse outcomes for LGBT+ populations compared with before COVID-19 pandemic or compared with heterosexual/ cisgender populations, suggesting worsening health inequities. With so little data, it was not possible to discern if any of the LGBT+ populations were faring any worse than any other. All studies were small, mostly of relatively 
Table 2 Results-surveys with concurrent control

\begin{tabular}{|c|c|c|c|c|c|c|c|}
\hline Source (date) & Outcome & Lesbian & Gay & Bisexual & $\begin{array}{l}\text { Heterosexual/ } \\
\text { comparator }\end{array}$ & $\begin{array}{l}\text { Trans male } \\
\text { and trans } \\
\text { female }\end{array}$ & $\begin{array}{l}\text { Cis male and } \\
\text { cis female } \\
\text { comparator }\end{array}$ \\
\hline \multirow[t]{3}{*}{$\begin{array}{l}\text { Barnardo's } \\
\text { (Sept 2020) }\end{array}$} & $\begin{array}{l}\text { Mental health significant } \\
\text { obstacle }\end{array}$ & NR & NR & NR & N/A & $34.3 \%$ & $\begin{array}{l}\text { Girls } 14.3 \% \\
\text { Boys } 13.2 \%\end{array}$ \\
\hline & $\begin{array}{l}\text { Feel lonely or isolated all of } \\
\text { the time }\end{array}$ & NR & NR & NR & N/A & $39.2 \%$ & $\begin{array}{l}\text { Girls } 15.0 \% \\
\text { Boys } 14.0 \%\end{array}$ \\
\hline & $\begin{array}{l}\text { Support need to improve } \\
\text { mental health }- \text { alcohol/drug } \\
\text { use support }\end{array}$ & NR & NR & NR & $\mathrm{N} / \mathrm{A}$ & $21.9 \%$ & $\begin{array}{l}\text { Girls } 3.6 \% \\
\text { Boys } 8.1 \%\end{array}$ \\
\hline $\begin{array}{l}\text { Healthwatch } \\
\text { Together } \\
\text { (June/July 2020) }\end{array}$ & $\begin{array}{l}\text { Suffered with mental health } \\
\text { issues }\end{array}$ & 65\% (LGB) & & & $32 \%$ & NR & NR \\
\hline \multirow[t]{6}{*}{$\begin{array}{l}\text { Outlife } \\
\text { (June 2020) }\end{array}$} & $\begin{array}{l}\text { Depression 'often', 'very } \\
\text { often' or 'every day' }\end{array}$ & $64.3 \%$ & $50.9 \%$ & $64.5 \%$ & $54.2 \%$ & $75.7 \%$ & $56.2 \%$ \\
\hline & $\begin{array}{l}\text { Anxiety 'often', 'very often' or } \\
\text { 'every day' }\end{array}$ & $67.5 \%$ & $56.6 \%$ & $70.5 \%$ & $50.0 \%$ & $77.0 \%$ & $62.2 \%$ \\
\hline & $\begin{array}{l}\text { Loneliness 'often', 'very } \\
\text { often' or 'every day' }\end{array}$ & $75.7 \%$ & $58.8 \%$ & $75.6 \%$ & $75 \%$ & $79.3 \%$ & $68.3 \%$ \\
\hline & $\begin{array}{l}\text { Self-harm 'often', 'very often' } \\
\text { or 'every day' }\end{array}$ & $16.0 \%$ & $6.6 \%$ & $15.3 \%$ & $20.8 \%$ & $21.6 \%$ & $11.3 \%$ \\
\hline & $\begin{array}{l}\text { Alcohol 'a few times a week' } \\
\text { or 'every day' }\end{array}$ & $22.8 \%$ & $32.6 \%$ & $20.5 \%$ & $22.7 \%$ & $20.2 \%$ & $25.2 \%$ \\
\hline & $\begin{array}{l}\text { Exercise once per month or } \\
\text { less }\end{array}$ & $16.6 \%$ & $21.0 \%$ & $18.5 \%$ & $26.1 \%$ & $21.6 \%$ & $18.4 \%$ \\
\hline
\end{tabular}

GPs, general practitioners; N/A, not applicable; NR, not reported.

low quality academically, and with limited numbers of outcomes that they could report, given the resources available. There was very little information on difference in rates in male and female trans and non-binary people, as most studies combined the trans sample, presumably because of low numbers. All comparative studies had fewer than 40 participants in one of the groups, limiting potential for finding statistically significant results.

There was no research found on the incidence, symptom severity, hospitalisations or death rates from COVID-19 in UK LGBT+ populations compared with heterosexual/cisgender populations. One small study ${ }^{39}$ reported numbers who had had COVID-19 up to July $2020-5$ of 103 respondents.

\section{Strengths and weaknesses of the systematic review}

This is the first systematic review examining UK-related COVID-19 research in LGBT+ populations. Currently, the PROSPERO database lists two other protocols, both unpublished and investigating mental health in LGBT+ communities only.

A major strength of this systematic review is the inclusion of grey literature. Extensive database searches found no peer-reviewed published UK research. A previous systematic review on LGBT health ${ }^{42}$ also found several grey literature studies reporting valuable information not available in peer-reviewed academic literature, so including grey literature due to paucity of published research is not new. However, it is disappointing that standard data collection does not yet include SOGI, and its reporting in peerreviewed, published health inequalities research. The current systematic review was conducted to the highest standards by experts in systematic reviewing and LGBT+ health, and is likely to have included all available relevant studies. Another major strength is the efforts made to find unpublished research by contacting experts, sifting UK Select Committee Public enquiry submissions ${ }^{25}$ and checking specialist websites. A weakness is the difficulty in making meaningful sense of the included studies' results, given their small size, relatively low quality and lack of suitable comparators. They were mostly carried out by poorly funded charities, whose budgets dramatically reduced because of the pandemic, ${ }^{43}$ and without these reports there would be no evidence at all. There is sometimes a potential bias in charity-sponsored research in 


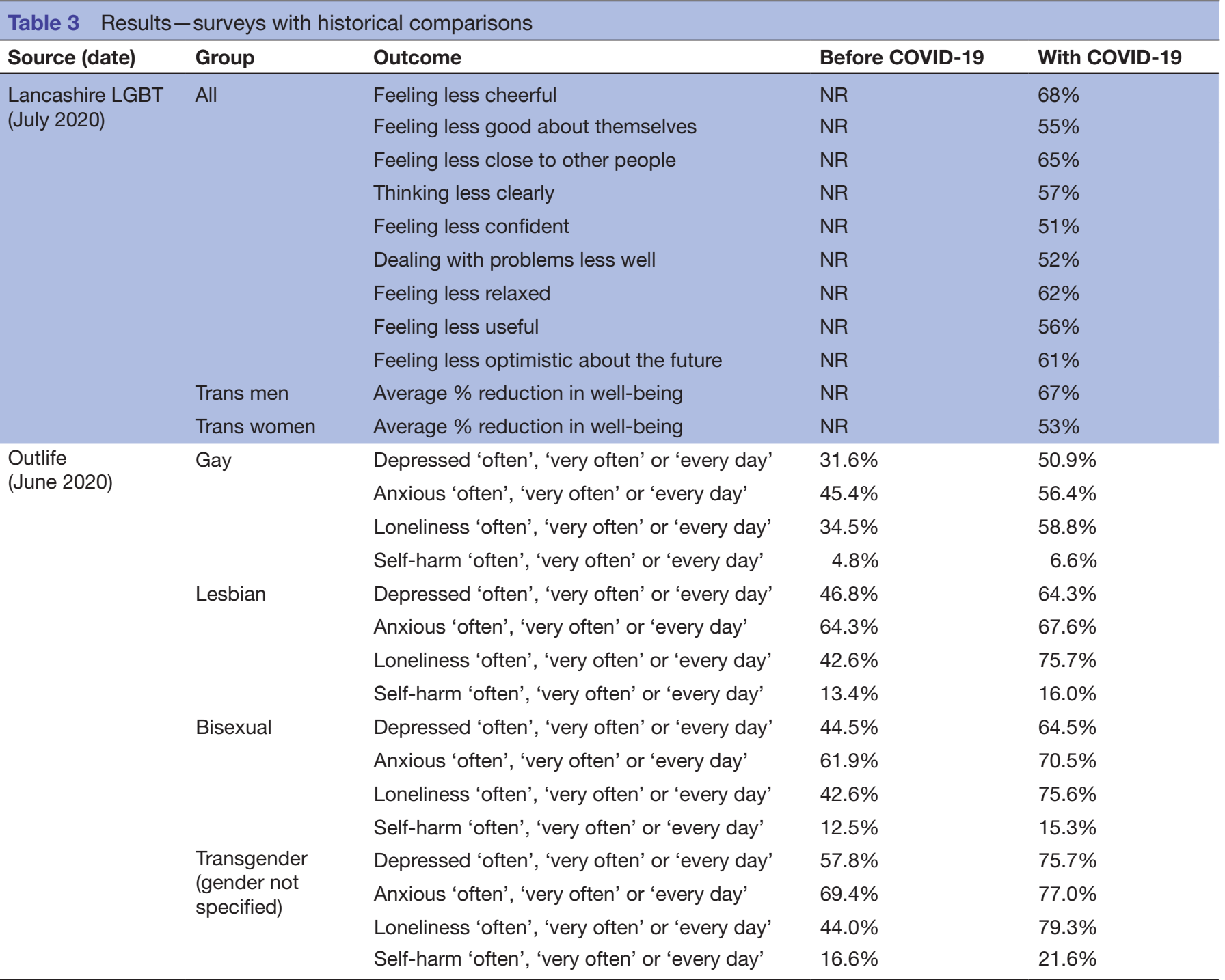

LGBT, lesbian, gay, bisexual and transgender; NR, not reported.

that they can conduct research to find problems to solve, but this could be clarified by independent, peer-reviewed and published research, should it become available.

\section{Meanings and implications of the systematic review}

Given that an estimated 5\% of the UK population is not heterosexual, ${ }^{44}$ and that there are between 200000 and 500000 transgender people in the $\mathrm{UK}^{6}{ }^{6}$ this lack of information is surprising and very worrying. Given the UK government's recent investment in LGBT+ health, ${ }^{75}$ it is unclear why none of the large UK-based COVID-19 surveys included SOGI demographics. There has been a validated measure of sexual orientation available for over 10 years, and the UK Census 2021 measured both sexual orientation and gender identity, so these question sets are freely available. The answer perhaps could lie in more general reluctance to ask about these demographic characteristics.

Institutional homophobia is a relatively new concept, and has been defined ${ }^{46}$ as:
The collective failure of an organisation to provide an appropriate and professional service to people because of their sexuality. It can be detected in processes, attitudes and behaviour which amount to discrimination through unwitting prejudice, ignorance, thoughtlessness and stereotyping.

Official data collection that ignores SOGI as a category is a subtle form of institutional homophobia/transphobia. A major implication for policymakers is to address why SOGI questions have been omitted, and ascertain whether it is this due to institutional homophobia/transphobia. One of the included studies ${ }^{34}$ made the following statement:

Despite our best efforts, this study was not funded by the UKRI (ESRC) COVID-19 Research initiative. At time of writing $£ 0$ (out of $£ 90491960$ ) had been awarded by the UK Research Councils to projects studying the experiences of the LGBTQ+ community during the coronavirus pandemic. 
Table 4 Results-non-comparative survey results for healthcare

\begin{tabular}{|c|c|c|c|c|}
\hline Source (date) & General mental health & $\begin{array}{l}\text { General physical } \\
\text { health }\end{array}$ & $\begin{array}{l}\text { Alcohol or other } \\
\text { substance consumption }\end{array}$ & Routine healthcare access \\
\hline $\begin{array}{l}\text { Birmingham LGBT } \\
\text { (Sept 2020) }\end{array}$ & $\begin{array}{l}65 \% \text { felt their mental health } \\
\text { had been affected since the } \\
\text { start of the COVID-19 outbreak } \\
60 \% \text { reported feeling anxious, } \\
\text { depressed or lonely } \\
14 \% \text { had suicidal or self- } \\
\text { harming thoughts }\end{array}$ & $\begin{array}{l}50 \% \text { of people stated } \\
\text { diet less healthy } \\
7 \% \text { accessed a food } \\
\text { bank } \\
70 \% \text { reported 'good' or } \\
\text { 'excellent' sexual health } \\
20 \% \text { undertook no } \\
\text { physical exercise }\end{array}$ & $\begin{array}{l}33 \% \text { indicated increased } \\
\text { use of recreational drugs } \\
40 \% \text { of those who drank } \\
\text { reported increased alcohol } \\
\text { consumption }\end{array}$ & $\begin{array}{l}12 \% \text { were not able to access } \\
\text { healthcare when they needed it } \\
11 \% \text { could not access } \\
\text { medication they needed }\end{array}$ \\
\hline $\begin{array}{l}\text { Houghton and Tasker } \\
\text { (Aug 2020) }\end{array}$ & $\begin{array}{l}70 \% \text { felt very or extremely } \\
\text { emotionally affected by the } \\
\text { pandemic }\end{array}$ & NR & NR & NR \\
\hline $\begin{array}{l}\text { Kneale and Becares } \\
\text { (Aug 2020) }\end{array}$ & \multicolumn{4}{|c|}{ (See separate table in online supplemental file) } \\
\hline $\begin{array}{l}\text { LGBT Foundation } \\
\text { (May 2020) }\end{array}$ & $\begin{array}{l}37 \% \text { had decreased mental } \\
\text { well-being as one of their top } \\
\text { three concerns } \\
42 \% \text { would like to access } \\
\text { support for their mental health }\end{array}$ & NR & $\begin{array}{l}18 \% \text { are concerned that } \\
\text { COVID- } 19 \text { will lead to } \\
\text { substance or alcohol } \\
\text { misuse, or trigger relapse }\end{array}$ & $\begin{array}{l}16 \% \text { had been unable to } \\
\text { access healthcare for non- } \\
\text { COVID-19-related issues } \\
34 \% \text { had a medical } \\
\text { appointment cancelled } \\
23 \% \text { were unable to access } \\
\text { medication }\end{array}$ \\
\hline $\begin{array}{l}\text { Opening Doors London } \\
\text { (Nov 2020) }\end{array}$ & $\begin{array}{l}>50 \% \text { felt that lockdown } \\
\text { impacted negatively on their } \\
\text { psychological well-being } \\
38 \% \text { felt more unhappy or } \\
\text { depressed since lockdown } \\
18 \% \text { felt much more } \\
\text { depressed than usual }\end{array}$ & $\begin{array}{l}5 \% \text { contracted } \\
\text { coronavirus } \\
23 \% \text { felt their physical } \\
\text { health was worse since } \\
\text { the pandemic and } \\
\text { lockdown }\end{array}$ & NR & NR \\
\hline
\end{tabular}

LGBT, lesbian, gay, bisexual and transgender; NR, not reported.

It needs to be established as to why has there been zero funding into the incidence, symptom severity, hospitalisations or death rates from COVID-19 in LGBT+ populations compared with heterosexual/cisgender populations, in spite of the $£ 500$ million UK Research and Innovation Economic and Social Research Council COVID-19 Research Initiative funding available. ${ }^{47}$ It also needs to be established if institutional homophobia/transphobia is the cause of a lack of good-quality COVID-19 research in UK LGBT+ populations.
The evidence in this systematic review was collected mostly by LGBT+ sector charities. If it had not been for these, almost no information on the impact of COVID-19 would have been available, yet this sector is considerably underfunded, ${ }^{48}$ and is facing a massive drop in income because of the COVID-19 pandemic. $^{49}$

The only evidence on the proportion of LGBT+ people who have had COVID-19 was 5 in 103 respondents, as of July $2020 .^{39}$ By this time, there had been 302301 confirmed COVID-19 cases in the UK, ${ }^{50}$ from a 
Table 5 Results-non-comparative survey results for well-being

\begin{tabular}{|c|c|c|c|}
\hline Source (date) & Personal safety & $\begin{array}{l}\text { Connecting with friends and } \\
\text { social support }\end{array}$ & Outness \\
\hline $\begin{array}{l}\text { Birmingham LGBT } \\
\text { (Sept 2020) }\end{array}$ & $\begin{array}{l}7 \% \text { reported experiencing a } \\
\text { hate crime since the start of the } \\
\text { pandemic } \\
5 \% \text { of respondents indicated they } \\
\text { had experienced domestic abuse } \\
\text { from a current or ex-partner or family } \\
\text { member since the start of lockdown }\end{array}$ & $\begin{array}{l}60 \% \text { indicated they had no } \\
\text { emotional support } \\
25 \% \text { reported knowing someone } \\
\text { who had died from COVID-19 } \\
\text { (7\% had lost family member/s, } \\
14 \% \text { friend/s, } 6 \% \text { relative/s, } 3 \% \\
\text { neighbour/s) }\end{array}$ & $\begin{array}{l}20 \% \text { were worried about being their } \\
\text { authentic self through lockdown }\end{array}$ \\
\hline $\begin{array}{l}\text { Houghton and Tasker } \\
\text { (Aug 2020) }\end{array}$ & $\begin{array}{l}26 \% \text { felt either very or extremely } \\
\text { uncomfortable where they were } \\
\text { living }\end{array}$ & $\begin{array}{l}28 \% \text { in relationships felt very } \\
\text { or extremely isolated from their } \\
\text { partner(s) } \\
59 \% \text { felt very or extremely isolated } \\
\text { from LGBTQ friends, compared with } \\
46 \% \text { felt very or extremely isolated } \\
\text { from cis or heterosexual friends }\end{array}$ & $\begin{array}{l}19 \% \text { felt very or completely } \\
\text { suffocated due to not being able } \\
\text { to express their LGBTQ* identity } \\
\text { where they were currently living }\end{array}$ \\
\hline
\end{tabular}

\begin{tabular}{|c|c|c|c|}
\hline $\begin{array}{l}\text { Kneale and Becares } \\
\text { (Aug 2020) }\end{array}$ & (See separate table in online supple & lental file) & \\
\hline $\begin{array}{l}\text { Lancashire LGBT } \\
\text { (July 2020) }\end{array}$ & $\begin{array}{l}11 \% \text { concerned about this } \\
8 \% \text { experienced domestic violence } \\
7 \% \text { had hate incident }\end{array}$ & $\begin{array}{l}55 \% \text { concerned about this } \\
60 \% \text { were not keeping in contact } \\
\text { with people from LGBT groups }\end{array}$ & $\begin{array}{l}34 \% \text { of did not feel able to be open } \\
\text { about SOGI in their home/living } \\
\text { environment }\end{array}$ \\
\hline $\begin{array}{l}\text { Live Through This } \\
\text { (Aug 2020) }\end{array}$ & NR & $\begin{array}{l}55 \% \text { worried about not seeing their } \\
\text { friends or family } \\
43 \% \text { concerned about social } \\
\text { isolation }\end{array}$ & $\begin{array}{l}9 \% \text { are not out to anyone in their } \\
\text { medical team }\end{array}$ \\
\hline $\begin{array}{l}\text { LGBT Foundation } \\
\text { (May 2020) }\end{array}$ & $\begin{array}{l}8 \% \text { do not feel safe where they are } \\
\text { currently staying }\end{array}$ & $\begin{array}{l}64 \% \text { said they would rather receive } \\
\text { support during COVID- } 19 \text { from an } \\
\text { LGBT-specific organisation }\end{array}$ & NR \\
\hline $\begin{array}{l}\text { LGBT South West, } \\
\text { Intercom Trust } \\
\text { (July 2020) }\end{array}$ & $\begin{array}{l}9 \% \text { did not feel safe where they } \\
\text { were currently staying }\end{array}$ & $\begin{array}{l}63 \% \text { listed inability to see friends } \\
\text { and family as their top concern at } \\
\text { this time } \\
58 \% \text { would prefer to receive support } \\
\text { from an LGBT+-specific organisation }\end{array}$ & NR \\
\hline
\end{tabular}

LGBT+, lesbian, gay, bisexual, transgender, non-binary, intersex and queer; NR, not reported; SOGl, sexual orientation or gender identity.

population of approximately 54 million adults, giving a proportion of roughly $0.6 \%$ of the population having had a confirmed case. However, according to an ONS study, as of 9 August 2020, $6.2 \%$ (95\% CI: $5.1 \%$ to $7.5 \%$ ) people aged 16 years and over tested positive for antibodies to COVID- $19,{ }^{51}$ but around $20 \%$ of these may have been asymptomatic, ${ }^{52}$ so the estimate of $4.9 \%,{ }^{33}$ although from a small sample, may be fairly similar to the UK population proportion.

\section{Unanswered questions and future research}

It became apparent early in the pandemic that men were more at risk of serious illness and death from COVID-19 than women. It could have been very useful to find out if transgender women had higher rates than transgender men, or vice versa. This might have started to answer the questions around whether higher rates in men were due to sex hormone levels, $\mathrm{Y}$ chromosome effects or other reasons. If pockets of unexpectedly high transmission in certain areas are found, it could be useful to check whether this may have happened due to social sex in some gay men. The evidence suggests that social controls implemented because of the pandemic have exacerbated mental health difficulties, and therefore investigating whether there have been higher suicide rates in LGBT+ populations would be appropriate. However, foremost in the list of unanswered questions that must be addressed is why SOGI measures are not yet included in demographic datasets of all large cohort studies, when the question 
sets are readily available. It needs to be established as to whether this is due to institutional homophobia/transphobia and how can this be reversed.

\section{CONCLUSIONS}

In this novel and rigorously conducted systematic review of the effects of the COVID-19 pandemic on the health and well-being of UK LGBT+ populations, no published research was found, and 11 small, grey literature reports of relatively low quality were included. Mental health and well-being, health behaviours, safety, social connectedness and access to routine healthcare tended to show poor outcomes, or worse outcomes from the LGBT+ populations compared with before the COVID-19 pandemic or compared with heterosexual/cisgender populations. No research was found on incidence, symptom severity, hospitalisations or death rates. Lack of research is a significant concern, especially when considering pre-existing health inequities between LGBT+ and heterosexual/ cisgender populations. Paucity of evidence is driven by lack of routinely collected SOGI data possibly resulting from institutional homophobia/transphobia which needs to be addressed.

Acknowledgements Cici Carey-Stuart from Encompass Network for alerting us to one of the included studies.

Contributors CM developed the original idea with discussions with LGBT activists and researchers. CM did the searches, HJL did double citation checking with CM and also looked on Google for additional studies. VJM conducted the systematic review double data extraction with $\mathrm{CM}$. CM wrote the initial draft of the manuscript and all authors edited it.

Funding VJM is funded by the National Institute for Health Research (NIHR) School for Public Health Research (SPHR) (grant reference number PD-SPH-2015). The NIHR SPHR is a partnership between the Universities of Sheffield; Bristol; Cambridge; Imperial; and University College London; The London School for Hygiene and Tropical Medicine (LSHTM); LiLac-a collaboration between the Universities of Liverpool and Lancaster; and Fuse-the Centre for Translational Research in Public Health, a collaboration between Newcastle, Durham, Northumbria, Sunderland and Teesside Universities.

Disclaimer The views expressed are those of the authors and not necessarily those of the NIHR or the Department of Health and Social Care.

Competing interests None declared.

Patient consent for publication Not required.

Provenance and peer review Not commissioned; externally peer reviewed.

Data availability statement Data sharing not applicable as no datasets generated and/or analysed for this study. This is a systematic review so data sharing not relevant.

Supplemental material This content has been supplied by the author(s). It has not been vetted by BMJ Publishing Group Limited (BMJ) and may not have been peer-reviewed. Any opinions or recommendations discussed are solely those of the author(s) and are not endorsed by BMJ. BMJ disclaims all liability and responsibility arising from any reliance placed on the content. Where the content includes any translated material, BMJ does not warrant the accuracy and reliability of the translations (including but not limited to local regulations, clinical guidelines, terminology, drug names and drug dosages), and is not responsible for any error and/or omissions arising from translation and adaptation or otherwise.

Open access This is an open access article distributed in accordance with the Creative Commons Attribution Non Commercial (CC BY-NC 4.0) license, which permits others to distribute, remix, adapt, build upon this work non-commercially, and license their derivative works on different terms, provided the original work is properly cited, appropriate credit is given, any changes made indicated, and the use is non-commercial. See: http://creativecommons.org/licenses/by-nc/4.0/.

\section{ORCID iDs}

Hayley J Lowther http://orcid.org/0000-0001-7500-0513

Catherine Meads http://orcid.org/0000-0002-2368-0665

\section{REFERENCES}

1 Marmot M, Allen J, Goldblatt P. Build Back Fairer: The COVID-19 Marmot Review. In: The pandemic, socioeconomic and health inequalities in England. London: Institute of Health Equity, 2020.

2 Bambra C, Riordan R, Ford J, et al. The COVID-19 pandemic and health inequalities. J Epidemiol Community Health 2020;74:964-8.

3 Booker CL, Rieger G, Unger JB. Sexual orientation health inequality: evidence from Understanding Society, the UK Longitudinal Household Study. Prev Med 2017;101:126-32.

4 von der Leyen U. State of the Union address by president von der Leyen at the European Parliament plenary. Available: https://ec. europa.eu/commission/presscorner/detail/en/SPEECH_20_1655 [Accessed 30 Dec 2020].

5 Madrigal-Borloz V. ASPIRE guidelines on COVID-19 response and recovery free from violence and discrimination based on sexual orientation and gender identity. United nations, human rights, special procedures, 2020. Available: https://www.ohchr.org/en/issues/sexu alorientationgender/pages/index.aspx [Accessed 30 Dec 2020].

6 Government Equalities Office. National LGBT survey research report. UK government, 2018. Available: https://www.gov.uk/government/ publications/national-lgbt-survey-summary-report [Accessed 30 Dec 2020].

7 Government Equalities Office. LGBT Action Plan. Improving the lives of lesbian, gay, bisexual and transgender people. UK government, 2018. Available: https://www.gov.uk/government/publications/lgbtaction-plan-2018-improving-the-lives-of-lesbian-gay-bisexual-andtransgender-people[Accessed 30 Dec 2020].

8 Semlyen J, King M, Varney J, et al. Sexual orientation and symptoms of common mental disorder or low wellbeing: combined metaanalysis of 12 UK population health surveys. BMC Psychiatry 2016;16:1-9.

9 Dhejne C, Van Vlerken R, Heylens G, et al. Mental health and gender dysphoria: a review of the literature. Int Rev Psychiatry 2016;28:44-57.

10 Jarrett BA, Peitzmeier SM, Restar A. Gender-affirming care, mental health, and economic stability in the time of COVID-19: a global cross-sectional study of transgender and non-binary people. medRxiv.

11 Suen YT, Chan RCH, Wong EMY. Effects of general and sexual minority-specific COVID-19-related stressors on the mental health of lesbian, gay, and bisexual people in Hong Kong. Psychiatry Res 2020;292:113365.

12 Torres TS, Hoagland B, Bezerra DRB, et al. Impact of COVID-19 pandemic on sexual minority populations in Brazil: an analysis of social/racial disparities in maintaining social distancing and a description of sexual behavior. AIDS Behav 2021;25:73-84

13 Santos G-M, Ackerman B, Rao A, et al. Economic, mental health, HIV prevention and HIV treatment impacts of COVID-19 and the COVID-19 response on a global sample of Cisgender gay men and other men who have sex with men. AIDS Behav 2021;25:311-21.

14 Shekhar S, Wurth R, Kamilaris CDC, et al. Endocrine conditions and COVID-19. Horm Metab Res 2020;52:471-84.

15 EMG Health. Female reproductive steroids may protect against COVID-19 symptoms. Available: https://www.emg-health.com/ omnipresent/female-reproductive-steroids-may-protect-againstcovid-19-symptoms/?utm_source=newsletter_repro\%20health\&utm _ medium=email\&utm_campaign=_091220 [Accessed 30 Dec 2020].

16 Hodson K, Meads C, Bewley S. Lesbian and bisexual women's likelihood of becoming pregnant: a systematic review and metaanalysis. BJOG 2017;124:393-402.

17 Harris A, Bewley S, Meads C. Sex hormone levels in Lesbian, bisexual, and heterosexual women: systematic review and exploratory meta-analysis. Arch Sex Behav 2020;49:2405-20.

18 Wozniak RJ, Nixon DF, Marston JL. Involvement of Cisgender and transgender individuals in studies on the impact of hormonal therapy on COVID-19. AIDS Patient Care STDS 2020;34:367-8.

19 Stephenson R, Chavanduka TMD, Rosso MT, et al. Sex in the time of COVID-19: Results of an online survey of gay, bisexual and other men who have sex with men's experience of sex and HIV prevention during the US COVID-19 epidemic. AIDS Behav 2021;25:40-8. 
20 Carvalho HEFde, Schneider G, Sousa ARde, et al. Suspected COVID-19 flu-like syndrome in men who have sex with men and have been involved in casual sex. Rev Bras Enferm 2020;73:e20200913.

21 Morani Z, Patel S, Ghosh S, et al. COVID-19 in HIV: a review of published case reports. SN Compr Clin Med 2020;2:2647-57.

22 Meyer IH, Prejudice MIH. Prejudice, social stress, and mental health in lesbian, gay, and bisexual populations: conceptual issues and research evidence. Psychol Bull 2003;129:674-97.

23 Lick DJ, Durso LE, Johnson KL. Minority stress and physical health among sexual minorities. Perspect Psychol Sci 2013;8:521-48.

24 Griffin JA, Casanova TN, Eldridge-Smith ED, et al. Gender minority stress and health perceptions among transgender individuals in a small metropolitan southeastern region of the United States. Transgend Health 2019;4:247-53.

25 Women and Equalities Select Committee. Inquiry. Unequal impact: coronavirus (Covid-19) and the impact on people with protected characteristics. Available: https://committees.parliament.uk/work/ 227/unequal-impact-coronavirus-covid19-and-the-impact-onpeople-with-protected-characteristics/publications/ [Accessed 30 Dec 2020].

26 Outlife. The LGBTQ+ Lockdown wellbeing report, 2020. Available: https://www.outlife.org.uk/the-lgbtq-lockdown-wellbeing-report [Accessed 30 Dec 2020].

27 Joanna Briggs Institute. Checklist for analytical cross-sectional studies. Available: https://joannabriggs.org/critical-appraisal-tools [Accessed 30 Dec 2020].

28 Critical Appraisal Skills Programme. Checklists. Available: https:// casp-uk.net/casp-tools-checklists/[Accessed 30 Dec 2020]

29 Barnardo's London. Listening to young Londoners: a digital listening project. Barnardo's, London, 2020, 2020. Available: https://www. barnardos.org.uk/news/barnardos-london-launches-new-digitallistening-report [Accessed 30 Dec 2020].

30 Viner D. Impact of COVID-19 on LGBT communities. Birmingham LGBT, Birmingham, 2020. Available: https://blgbt.org/wp-content/uploads/ 2020/09/Impact-of-Covid-19-on-LGBT-community.pdf [Accessed 30 Dec 2020].

31 Healthwatch Cumbria. The impact of the coronavirus pandemic on the LGBTQ community. Healthwatch together, 2020. Available: https:// healthwatchcumbria.co.uk/news/lgbtq-and-covid-19-healthwatchtogether-publish-new-report/[Accessed 30 Dec 2020].

32 Healthwatch Cumbria. How are you coping with the coronavirus (Covid-19) pandemic? summary report 2 (overview of version 2 of the survey). Healthwatch together, 2020. Available: https:// healthwatchcumbria.co.uk/wp-content/uploads/2020/07/HWT-C19-v2report-June-2020-final.pdf [Accessed 30 Dec 2020.]

33 Houghton M, Tasker F. LGBTQ* UK COVID-19 Lockdown 18-35 experiences: first survey, preliminary results. Birkbeck University of London. London, 2020. Available: https://lgbtq1835c19lockdown.files. wordpress.com/2020/09/1st-survey-prelim-results-report-18sep2020.pdf [Accessed 30 Dec 2020].

34 Kneale D, Bécares $L$. The mental health and experiences of discrimination of LGBTQ+ people during the COVID-19 pandemic: initial findings from the Queerantine study. medRxiv.

35 Lancashire LGBT. Covid-19 lockdown survey report, 2020. Available: https://lancslgbt.org.uk/lancashire-lgbt-covid-19-lockdown-surveyreport/ [Accessed 30 Dec 2020].
36 LGBT Foundation. Hidden figures: The impact of the covid-19 pandemic on LGBT communities in the UK - 3rd edition, 2020. Available: https://lgbt.foundation/hiddenfigures [Accessed 30 Dec 2020].

37 LGBT+ Southwest Voices. The impact of the Covid-19 pandemic on our communities: the Intercom trust, 2020. Available: https://www. intercomtrust.org.uk/item/221-survey-results [Accessed 30 Dec 2020].

38 Live Through This. Cancer \& COVID in our community: experiences of the coronavirus pandemic from LGBTIQ+ people affected by cancer, 2020 . Available: https://livethroughthis.co.uk/update/reportccc/[Accessed 30 Dec 2020].

39 Opening Doors London. Only connect: the impact of covid-19 on older LGBT+ people, 2020. Available: https://www. openingdoorslondon.org.uk/news/connect-only [Accessed $30 \mathrm{Dec}$ 2020]

40 Fish J, Almack K, Hafford-Letchfield T, et al. What are LGBT+ inequalities in health and social Support-Why should we tackle them? Int J Environ Res Public Health 2021;18:3612.

41 McDermott E, Nelson R, Weeks H. The politics of LGBT+ health inequality: conclusions from a UK scoping review. Int J Environ Res Public Health 2021;18:826.

42 Meads C, Carmona C. Lesbian, gay and bisexual people's health in the UK: A theoretical critique and systematic review. Divers Health Care 2012;9:19-32.

43 Mahase E. Covid-19: charity cuts could put the NHS under even more pressure. BMJ 2020;370:m3261.

44 Office for National Statistics. Sexual identity, 2018. Available: https:// www.ons.gov.uk/peoplepopulationandcommunity/culturalidentity/ sexuality [Accessed 31 Dec 2020].

45 NHS England. LGBT health. Available: https://www.england.nhs.uk/ about/equality/lgbt-health/ [Accessed 30 Dec 2020].

46 Ozanne J. What is institutionalized homophobia? Available: https:// www.episcopalcafe.com/what-is-institutionalized-homophobia/ [Accessed 30 Dec 2020].

47 UK Research and Innovation. Tackling the impact of COVID-19. Available: https://www.ukri.org/our-work/tackling-the-impact-ofcovid-19/[Accessed 31 Dec 2020].

48 The Guardian Newspaper. Lesbian and gay groups face funding crisis, 2014. Available: https://www.theguardian.com/society/2014/ sep/03/lesbian-gay-transgender-community-groups-funding-crisiscuts [Accessed 31 Dec 2020].

49 Consortium National LGB\&T Partnership. COVID-19 and LGBTQ+ communities. Available: https://www.consortium.lgbt/nationallgbtpart nership/covid-19/ [Accessed 31 Dec 2020].

50 Statista. Number of coronavirus (COVID-19) cases in England as of July 30, 2020, by age and gender, 2020. Available: https://www. statista.com/statistics/1115083/coronavirus-cases-in-england-byage-and-gender/ [Accessed 31 Dec 2020]

51 Office for National Statistics. Coronavirus (COVID-19) infection survey pilot: England and Wales, 2020. Available: https://www.ons. gov.uk/peoplepopulationandcommunity/healthandsocialcare/conditio nsanddiseases/bulletins/coronaviruscovid19infectionsurveypilot/engl andandwales14august2020 [Accessed 31 Dec 2020].

52 Pollock AM, Lancaster J. Asymptomatic transmission of covid-19. BMJ 2020;371:m4851. 